\title{
Structural and Petrographic Study of Crystalline Rocks in Part Of Oban Massif, South- Eastern Nigeria
}

\author{
${ }^{1}$ UBIT, GE; ${ }^{2}$ IBANGA, IM; ${ }^{2}$ BASSEY, NE; *2INIM, IJ \\ ${ }^{*}$ Department of Applied Geology, Abubakar Tafewa Belewa University, Bauchi, Nigeria \\ ${ }^{I}$ Department of Geology, Akwa-Ibom State University, Mkpat Enin,Nigeria \\ "Corresponding Author Email: iniememinim@yahoo.com
}

\begin{abstract}
The study aims at differentiating lithologic units, general structural trends and orogenic implications of crystalline rocks within part of Oban Massif, Southeastern Nigeria. Field study involve geological mapping, rock description and structural measurement, while laboratory analysis covered photomicrograph. Field observation and microscopic analysis reveal five petrological units; gneisses, schists, granodiorite, pegmatite and quartz veins. The rocks are generally siliceous and quartzo-feldspathic. The schist show foliation planes trending majorly in the NE-SW direction. The gneisses were highly fractured, indicative of a polyphase deformation. Structural elements such as joints, fractures, foliations and veins show series of deformational episodes that affected the area. Rose diagram plot for these structures show the NE-SW direction indicative of the Pan-African orogeny $(600 \pm 150 \mathrm{Ma})$ and interpreted as the most recent event affecting the area. NW and NE trending joints are considered to be tectonic in origin based on their alignments with major structures of the area. Furthermore, the structures also showed weak NW-SE and E-W trends, an imprint of older (Kibaran orogeny) deformational episodes.
\end{abstract}

DOI: https://dx.doi.org/10.4314/jasem.v25i12.4

Copyright: Copyright (C) 2021 Ubit et al. This is an open access article distributed under the Creative Commons Attribution License (CCL), which permits unrestricted use, distribution, and reproduction in any medium, provided the original work is properly cited.

Dates: Received: 22 August 2021; Revised: 17 September 2021; Accepted: 06 October 2021

Keywords: Oban Massif, Geologic structures, Orogeny, Basement Complex, lithologies

The Nigerian Precambrian Basement Complex is made up of migmatitic banded gneisses and migmatites, weakly migmatized to unmigmatized paraschists also referred to as "Younger Metasediments" or "Schist belts", and the Older Granite suite comprising mainly granites/granitoids, granodiorites, charnockites (hypersthene granites), syenites, as well as minor gabbroic and dioritic rocks. Unmetamorphosed dolerite and rhyolite porphyry dykes, pegmatite dykes, and numerous veins of quartzo-feldspathic composition are intrusions commonly found in the Basement Complex (Obiora $2005,2006)$. It covers about $60 \%$ of Nigeria's total landmass and extends to some neighbouring countries like Cameroun (Rahman et al., 1981). The Nigerian Precambrian Basement Complex rocks are believed to be the results of at least four major orogenic cycles of deformation, metamorphism, reactivation, and remobilisation corresponding to the Liberian (2650 \pm $150 \mathrm{Ma})$, the Eburnean $(2000 \pm 50 \mathrm{Ma})$, the Kibaran $(1100 \pm 200 \mathrm{Ma})$, and the Pan-African cycles (600 \pm $150 \mathrm{Ma})$. Using the International Geologic Time Scale (2002), these ages can be referred to as, Paleoarchean to Mesoproterozoic (3600 to $1600 \mathrm{Ma}$ ) for Liberian and Eburnean, Mesoproterozoic to Neoproterozoic (1600 to $1000 \mathrm{Ma}$ ) for Kibaran, and Neoproterozoic to Early Paleozoic (1000 to $545 \mathrm{Ma}$ ) for Pan-African (Obiora, 2006). Each of these orogenies left its structural imprints on the Basement. Hence, complex structures are associated with the Nigerian Basement (Ekwueme, 1994). The opinion is, however, divided on the occurrence of these structural imprints. Some authors, McCurry (1976) and Rahaman (1976) are of the view that the last tectonothermal event (Pan African) was so pervasive that it obliterated earlier structures. Others advance the opinion that though pervasive, the Pan African event did not wholly homogenise the rocks in the Basement; hence, traces of earlier/structures remain (Grant 1978; Onyeagocha and Ekwueme 1982; Ekwueme 1987; Oluyide 1988). It is a consensus among the latter that the different orogenies produced distinct structural trends. Egesi and Ukaegbu $(2011,2013)$ and Obioha and Ekwueme, (2011) have studied the Precambrian basement rocks in the Obudu, Obalinku and Boki areas, which is in the north and western parts of the study area. Oban massif covers about 100,000 $\mathrm{km}^{2}$ (Ekwueme, 1990) who considered it to have such mappable metamorphic rock units as phyllites, schists, gneisses, amphibolites with associated rocks such as charnockite. These rocks are intruded by pegmatite, granodiorite, granites, dolerites, diorite, monzonites and tonalities. Structurally, Rahaman (1976) opined that two phases of folding related to the Older granite orogeny (PanAfrican age $600 \pm 125 \mathrm{Ma}$ ) occurred in the Nigerian Basement complex. He also maintained that a N-S foliation trend characterises the Pan-African Orogeny due to persistent E-W stress. Major structural features include polyphase deformations involving foliation, major and minor folds, joints, faults and lineation. The Oban massif basement has undergone polyphase deformation involving folding, faulting, shearing, and 
fracturing. The dominant trend of the structural features of planar and linear types is N-S to NE-SW $\left(0-30^{\circ}\right)$. Minor trends in the NW-SE and E-W also occurred and have been interpreted as relicts of prePan African deformation episodes (Ekwueme, 1994). Ekwueme (1987) reported that the crustal evolution of the Oban massif was affected by Kibaran orogeny, which was dated 1313 - $1315 \mathrm{Ma}$ and that this event imprinted a weak NW-SE trending foliation on the rock. Thus, the pan-African event partially overprinted the rocks in these areas, thereby leaving relics of the Kibaran. This study aims to contribute to the scientific discussion on the petrology and structural settings of the study area.

Description Of Study Area: The study area is situtated in Akamkpa, Cross River (Nigeria), covering about $38.3 \mathrm{~km}^{2}$. It lies between latitude $8^{\circ} 15^{\prime}$ to $8^{\circ} 22^{\prime} 30^{\prime \prime} \mathrm{N}$ and longitudes $5^{\circ} 12^{\prime} 30^{\prime \prime}$ and $5^{\circ} 18^{\prime} 30^{\prime \prime} \mathrm{E}$ and includes villages such as Awi and Ayiebam, Isang-Inyang, Mbarakom and parts of Calaro oil palm estate camps. It is bounded to the North by Igbofia camp, on the east by Okom-Ita, and on the southeast by Uwet, all in Akampka area of Cross River state. The Oban massif forms part of the massive surge of the western elongation of the Cameroun Mountains into the crossriver plains of south-eastern Nigeria (Ekwueme, 2003). Mamfe Embayment bounds it to the north, Calabar flank, by the south, lower Benue Trough by the west, and the east, an extension of the Mamenda Massif (highlands of Cameroun mountain).

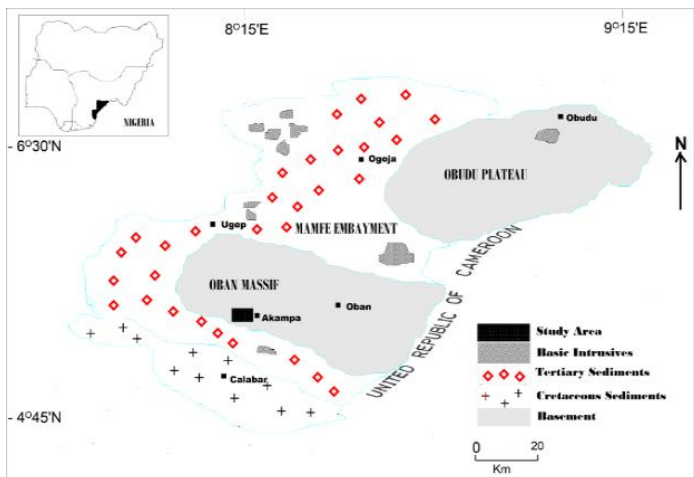

Fig. 1: Map of Cross River state showing the study area. (Modified after Iloeje, 1978)

\section{MATERIALS AND METHODS}

The method adopted in this study are standard mapping techniques as expressed by Morsley (1981), Ekwueme (2004) and Fayose (2011). During the mapping exercise the bearing and pacing technique along tracks and stream paths were used with regular incursions into the forest in a grid pattern to locate exposed outcrops. The rocks were observed and described based on mode of occurrence, macroscopic characteristics, structural elements and field relation with other rocks. Careful observation of lithological boundaries was made by observing changes in rock units, nature of the soil, vegetation, topography and thickness of overburdened soil. Description and measurements of structural elements were made using a compass clinometer to determine the attitudes (strikes, dips, dip directions, length and width) of structures . Fresh rock samples (hand specimen) were collected with the aid of geological hammer, and described based on color, texture, mineralogy and labelled. The dominant structures encountered in the study area are; joints, faults, lineations and foliations. Faults were mapped by observing displacement along their strikes evident by the presence of plumose structure or striations. Joints were mapped by observing areas in outcrops where cohesion is lost with no relative movement of the rocks along the fracture plane. The cross-cutting relationships between rocks were also carefully observed, described and recorded. All the attitudes of structures were measured and recorded for geometric analysis. Linear (lineations) and planar structures (foliations) were mapped carefully by identifying their trends or orientations.

Laboratory study involved preparing thin section of fresh samples collected for petrographic studies using the microscope. This petrographic work was carried out to determine the major rock types and mineral contents. Foliation, joints and fracture orientation data were also analysed, and their distributions are represented in a rose diagram to establish their preferred orientation. Lastly, a geologic map of the area with emphasis on structures was produced.

\section{RESULTS AND DISCUSSION}

Field description of geologic units: The major lithologies mapped are: gneiss, schist, and intrusives such as granodiorite, pegmatite and quartzofeldspathic veins (Fig. 2).

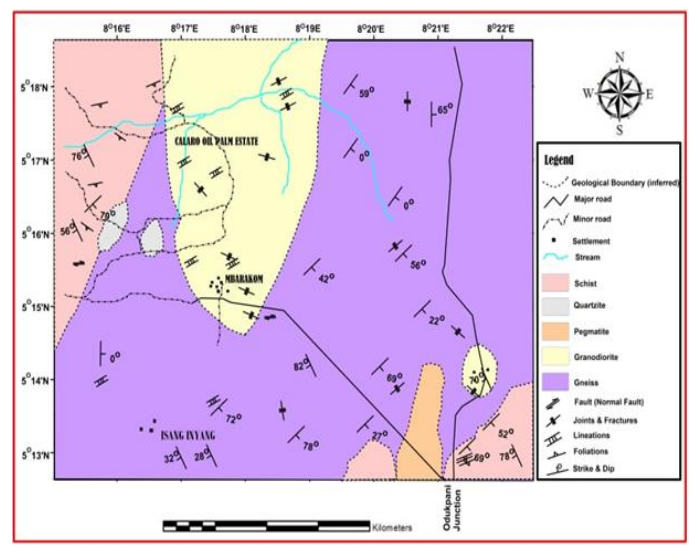

Fig. 2 Geological map of the study area 
Gneiss: The gneiss occur as large boulders of irregular sizes scattered around the study area. They occur as medium to coarse-grained in texture with alternating light and dark minerals bands (difference in the concentration of ferromagnesian and quartzofeldspathic minerals) exhibiting weak foliation. The gneiss outcrops are highly fractured, indicative of a polyphase deformation. These rocks formed by deepseated, high-grade regional metamorphism, and they mostly display a structural pattern indicative of PanAfrican orogeny, as shown by the trend of their foliation (N-E). Hand specimen and thin section descriptions show that they contain feldspars, quartz, biotite and hornblende.

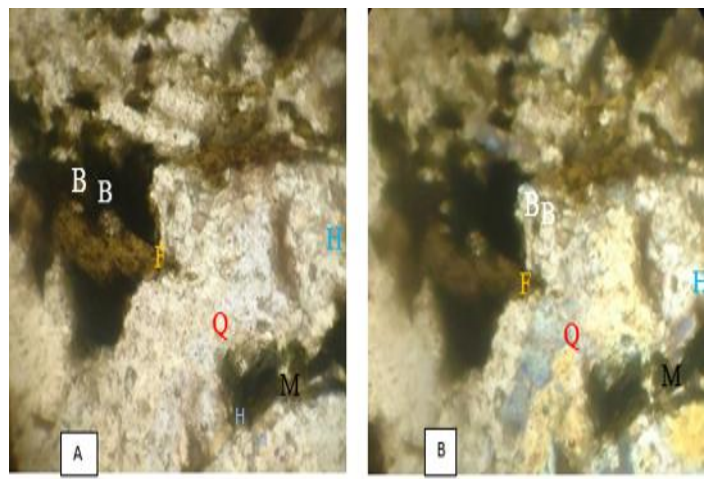

Fig. 3. Photomicrography of studied gneiss showing different minerals (F - Plagioclaise feldspar Q - Quartz, H - Hornblende B Biotite, M - Muscovite) Mag. x40 (a)PPL (b) XPL

The photomicrograph show the rock is characterised by plagioclase feldspar, dark brown in colour with lines across it, giving its characteristic cross twinning (Fig. 3a and 3b). Quartz is present as a colourless white mineral (Fig 3a and Fig 3b). Biotite is recognised as being dark in colour with cleavage and has no pleochroism. This rock was formed by deep-seated, crustal process generally confined to eroded fold mountain belts and Precambrian terrain (Ekwueme, 1993). Geochemical studies by Ekwueme and Onyeagocha (1985) reveal that the gneisses plot in the field of shale-graywackes. This means that they originated from shales.

Schists: Schists covered about $10 \%$ of the mapped area and are found within the northwestern and southeastern parts of the study area (Fig. 2). It is fine to medium-grained in texture, foliated with primary schistosity trend of NW - SE with an average dip of $40^{\circ}$ toward the east. Dominant minerals seen in hand specimens include mica, quartz and feldspar. The outcrops are brownish, due to chemical weathering. Schist is a foliated rock formed by regional metamorphism as it readily split into sheets. Its conspicuous schistosity is due to preferred mineral orientation of felsic bands alterations with mafic bands (Fig. 4).

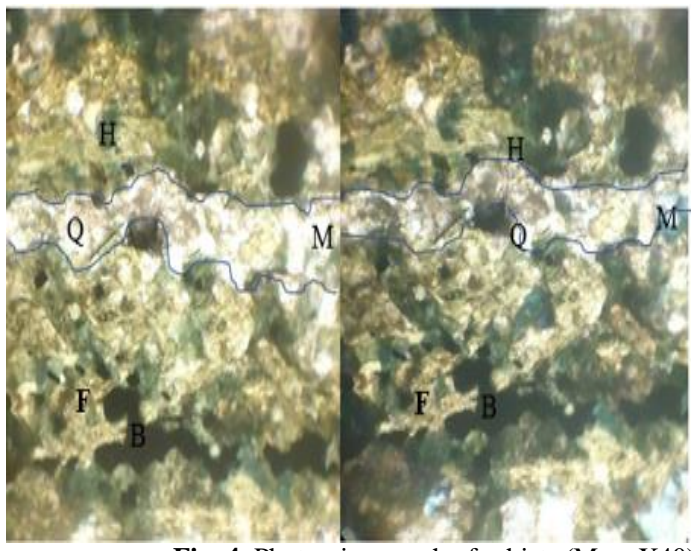

Fig. 4. Photomicrograph of schists (Mag. X40) showing minerals (Q- Quartz, B- Biotite H- Hornblende FPlagioclase feldspar M- Muscovite)

From Fig. 4a, quartz can be identified as a colourless white mineral with no pleochroism. Muscovite, which is also colourless appear bluish and yellowish under XPL (Fig 4b) due to its mild birefringence, these make up the felsic layer. In contrast, the mafic layer is identified by the presence of plagioclase feldspar identified by cross twinning and is brownish with mild pleochroism and biotite, dark in colour. Hornblende is found scattered in the rock as irregular anhedral mass having a dark green colouration.

Granodiorite: Granodiorite is the most dominant rock in the area. It occurs as in-situ boulders in some outcrop and shows a typical ex-foliation weathering pattern. The granodiorite has sharp contact with enclosing gneissic rocks. Generally, it is coarsegrained in texture and contains large pink phenocryst of $\mathrm{k}$-feldspar. Other minerals recognised in hand specimens are biotite, quartz, plagioclase and hornblende. The granodiorite is weakly foliated. The k-feldspars are subordinate to plagioclase. Microcline shows a characteristic cross-hatched twinning while orthoclase shows simple twinning. The plagioclase occurs as euhedral crystals with multiple twinning. Greenish-brown hornblende is present in the rock and has an intimate association with biotite.

Pegmatite: Pegmatites found in the study area vary in size and occurrence. Pegmatites, at times are is seen to have a unique and genetic association with the gneisses and schist of the area (Ekwueme, 1985). Some outcrops occur as scattered boulders ranging in size between 10-15 $\mathrm{m}$ in width and 2.5-3 $\mathrm{m}$ in height, while others occur mostly concordantly with their host rock varying in length from about $10 \mathrm{~m}$ to $199 \mathrm{~m}$ and width of about $0.5-30 \mathrm{~cm}$. They are also seen to occur 
in association with quartzite veins to mark a sort of gradational boundary between the gneisses and schists. Structurally, pegmatites are non-foliated though they generally trend N-S (Pan-African trend), which is the foliation trend and a plane of weakness in the countryrock. In hand specimens, pegmatites are generally coarse-grained with a characteristic graphic texture. Quartz, feldspars and muscovite are the dominant minerals. Garnet and other accessory minerals like tourmaline occur in some outcrops. Its crystals are large, reaching hundreds of centimetres in diameter. The occurrence of garnet in the pegmatite shows that they occurred as an intrusion in the gneiss.

Quartz veins: Quartz bodies occur as either veins or veinlets in the gneisses and granodiorite of the area. They are emplaced discordantly and concordantly with the country-rock (Fig 5a \& b). The veins measure about $1-20 \mathrm{~cm}$ in width, and some extend laterally to about 43.8-230 $\mathrm{m}$ along tractor roads and footpaths. The veins are generally medium to coarse-grained in texture.
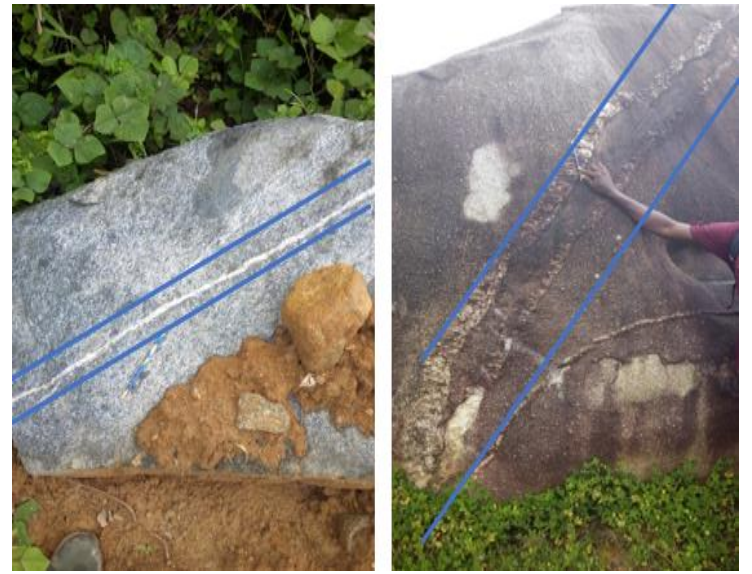

Fig. 5a and b. Quartz veinlet \& vein found as intrusion in Granodiorites in the study area

Geologic structures: Structures are the manifestation of the response of rock to varying deforming forces (tectonic and metamorphic) that affected an area. The Nigerian Basement complex has undergone polyphase deformation during the Precambrian (Oyawoye, 1972; McCurry, 1976; Rahaman, 1976; Ekwueme, 1987). It is worthy to note that these deformations had left their imprints as structures on the host rocks, which constitutes the area's structural geology.

Joints and fractures: These features are mainly seen in the gneisses and granodiorites than the schists where they form conjugate pairs (Fig. 6). The prominent joints and fractures set in the area trends NW-SE, (Fig. 7) Minor trends are NE-SW, E-W and NNW-ESE trends. They are common features in the mapped area
(Fig. 2), and their development is due to regional deformation by compression and stress relief. The NESW trends represent the imprints of the penetrative Pan-African deformation. In contrast, E-W and WNW-ESE trends are deciphered as representing relicts of the Pre-Pan-African deformation and metamorphism, possibly Kibaran.
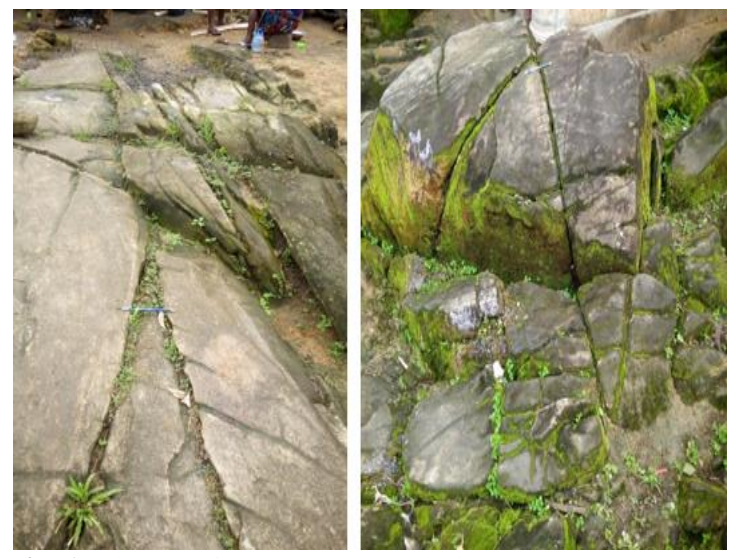

Fig. 6: Joints and fractures on granodiorite outcrop at Mbarakom

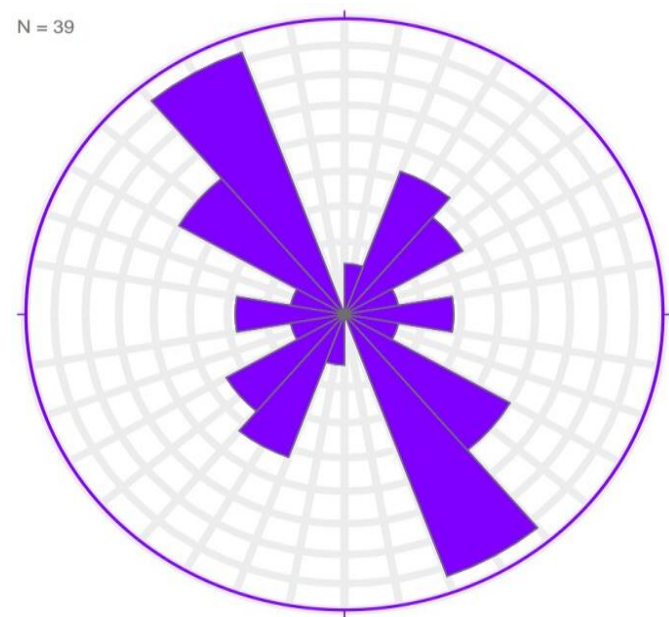

Fig. 7: Rose diagram plot of the joints and fractures found in the study area $(n=39)$

The presence of NE-SW, NW-SE and E-W fractures, joints, faults and dykes has been reported in the PanAfrican Basement of Nigeria by several studies (Ball, 1980; Okonny, 1984; Ike, 1988; Oluyide, 1988; Edet et al. 1994). In analysing the preferred orientation of phenocrysts of a porphyritic granitoid in the Oban massif, Oden (2012) observed a tendency for these megacrysts to align NW-SE direction, inferring that, the NW-SE trend was a preferred shear direction during the Pan-African orogeny. The presence of the $\mathrm{E}-\mathrm{W}$ fractures is interpreted as trajectories of the maximum principal stress during the Pan-African deformation (Ball, 1980). The NW-SE fractures are considerd in this study to be principally tectonic joints 
since they align with the NW direction of emplacement of the Oban Massif (Fig.1) same can be said of the NE fractures which align with the trend of the Benue Trough. No doubt a minor proportion of these joints may have been produced as a consequence of isostatic uplift of the Oban massif during formation of the adjoining Benue Trough of Nigeria.

Foliations and schistosity: Schistosity is the parallel alignment of micaceous minerals and compositional banding. It is a term used to describe the foliation in rocks with a grain size coarse enough to be called schist, the arbitrary boundary being placed at coarseness at which individual layer of silicates becomes discernible (Hobbs et al. 1976). This was observed in the schist of the study area. Ekwueme (1993) defined foliation as a directional fabric in which crystals of the metamorphic mineral assemblage display preferred orientation or banding due to deformation and recrystallisation. Foliations are also described by Hobbs et al. (1976) as pervasive structures defined by discontinuities, preferred orientation of in-equate minerals, laminar aggregate or some combination of these microstructures. The schist and gneiss in the study area show these structures, although they are weaker in the gneisses. The foliation is due to the arrangement of the minerals in a preferred orientation. The gneisses and schist also exhibit banding consisting of light and dark bands of minerals in which quartz and feldspar make up the light part, and mostly biotite and hornblende make up the dark part. The foliation data are plotted on a rose diagram (Fig.8).

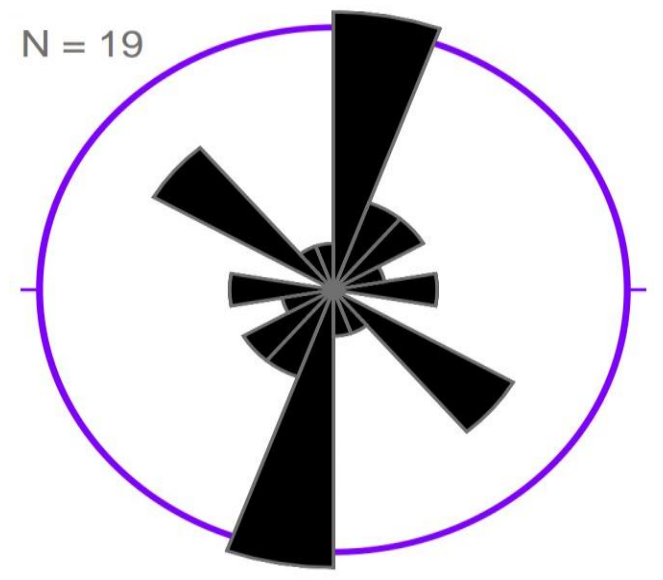

Fig.8: Rose diagram for foliations in the study area. $(n=19)$

The predominant trend of foliation is NE-SW with subordinate trend in the NW-SE direction. This is consistent with Ekwueme (1987) observation; that the $\mathrm{N}-\mathrm{S}$ to NE-SW trending foliation is more widespread than the NW-SE trend. These two foliation trends indicate that one phase (NE) is younger than the other
(NW) due to the different episodes of deformation that occurred in the area.

Faults: Faults are produced from forces acting within the earth crust, displacing or distorting the rocks. The forces are from the overlying rocks or the large-scale movement of the lithosphere. The faults found in the area were normal faults and were found within the granodiorites at Ayeibam and Mbarakom (Fig. 9) within the study area. Both dip at an angle of about $41^{\circ}$ and trending at $087^{\circ}$ and 098 which is an E-W trend. These faults could be genetically related to the E-W rifting of the Mamfe Embayment.

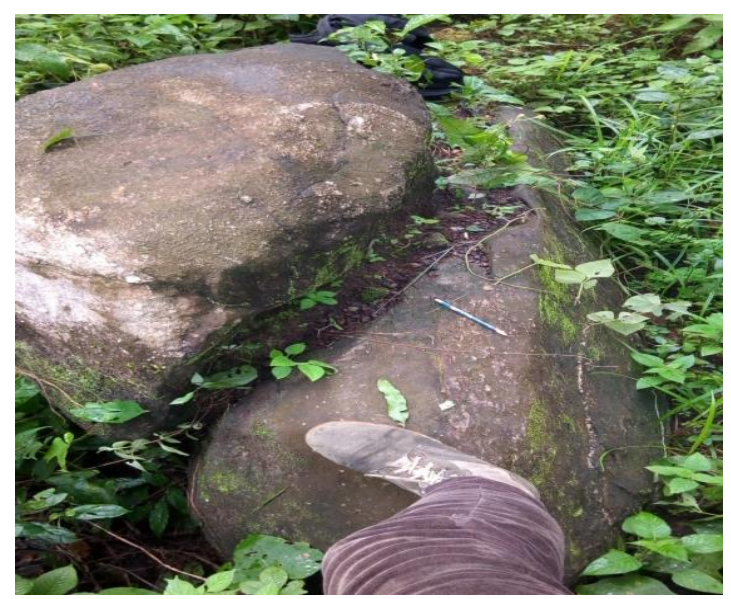

Fig. 9: A faulted Granodioritic at Mbarakom abandoned quarry

Conclusion: The field mapping of the study area reveals two distinct petrologic groups, the metamorphic rocks, under which are gneiss and schist, and the igneous rocks, which are mainly granite granodiorite, pegmatite, and quartz veins. A series of events affected the area's geology, leaving structural imprints on the rocks in features like joints, fractures, micro folds, lineations and foliations. Rose diagrams plotted for these structures showed the NE-SW direction indicative of the Pan-African orogeny considered as the most recent event affecting the area. These structures also showed a weak trend in the NWSE and E-W directions which are interpreted as imprints of an older deformational episode likely Kibaran orogeny, and post Pan-African deformation respectively. Nevertheless, NW and NE trending joints are considered to be tectonic joints as they align with the emplacement directioin of the Oban Massif, and the Benue Trough respectively.

\section{REFERENCES}

Ball, E (1980). An example of very consistent brittle deformation over a wide intercontinental area: the 
late Pan-African fracture system of the Tuareg and Nigerian shield. Tectonophysics, 61: 363-379.

Chukwu-Ike, IM; Norman, JW (1977). Mineralised crustal failures shown on satellite imagery of Nigeria. Inst. Mining \& Metal. Trans. (Sec. B:Applied Earth science), 86: B55-B57.

Edet, AE; Teme, SC; Okereke, CS; and Esu, EO (1994). Lineament analysis for groundwater exploration in Precambrian Oban Massif and Obudu plateau, SE Nigeria. J. Min. Geol., 30(1): 87-95.

Egesi, N;Ukaegbu, VU (2013). Petrologic and Structural Features of Basement Rocks of Parts of Mukuru Area, Southeastern Nigeria. Earth Sci. vol. 2, No. 4: 96-103.

Egesi, N; Ukaegbu, VU (2011). Petrology and Major Element Geochemistry of Late to PostNeoproterozoic Peraluminous Granitoids in parts of Bansara Southeastern Nigeria. The IUP J. Earth Sci. vol. 5 No. 3: 7-19.

Egesi, N; Ukaegbu, VU (2010). Petrologic and Structural Characteristics of the Basement Units of Bansara Area, south-eastern Nigeria. Pacific J. Sci. and Technol. (PJST) 11(1): 510 - 525.

Ekwueme, B. N. Field geology and geological map production and interpretation. Bachudo Science Co. Ltd. Calabar, Nigeria 165pEkwueme, BN (2003). The Precambrian Geology and Evolution of the Southeastern Nigeria Basement complex. University of Calabar Press, 135p.

Ekwueme, BN (1994). Structural features of Southern Obudu Plateau, Bamenda Massif, S-Nigeria: Preliminary Interpretations., Nigerian J. Min. and Geol. vol. 30, No. 1: 45 - 59.

Ekwueme, BN (1993). An Easy Approach to Metamorphic Petrology, University of Calabar Press, Calabar. Nigeria. pp. 169.

Ekwueme, BN (1990). Rb - Sr ages and petrologic features of Precambrian rocks from the Oban massif, southern Nigeria, Precamb Res., 47: 271286.

Ekwueme, BN (1987). Structural orientations and Precambrian deformational episodes of Uwet area, Oban massif, SE Nigeria, Precamb. Res., 34: 269-287.
Ekwueme, BN (1985), Petrologic, geochemistry and $\mathrm{Rb}$ - Sr geochronology of metamorphosed rocks of Uwet area, south-eastern Nigeria. Published Ph.D thesis, Univ. of Nigeria, Nsukka.

Ekwueme, BN; Ekwere, SJ (1989). The Geology of the eastern section of Oban Massif, Southeastern Nigeria. J. Min. Geol. vol. 25, pp. 372

Ekwueme, BN; Nyong, EE; Petters, SW (1995). Geological excursion guide book to Oban Massif, Calabar Flank and Mamfe embayment, S. E. Nigeria. Dc Ford Publisher's Ltd.

Ekwueme, BN; Onyeagocha, AC (1985). Petrology of intrusive in the Basement complex of Uwet area, Oban massif, south-eastern Nigeria. J. Min. Geol. 22: 71-78.

Fayose, E.A. 2011. Geological maps and their interpretation. Lighthouse Publishers Ltd. Ibadan, Nigeria 158p

Grant, NK (1978). Structural distinction between a metasedimentary cover and underlying Basement in 600M.Y. old Pan-African domain of northwestern Nigeria, West Africa. Geol. Soc. Am. Bull., 89: 50-58.

Hobbs, BE; Means, WP; Williams, PF (1976). An outline of Structural Geology, John Wiley \& Sons, New York. Pp. 571.

Ike, EC (1988). Late geological phenomena in the Zaria basement granites. In: P. O. Oluyide (Coordinator) Precambrian Geology of Nigeria. Geol. Surv. Nigeria Publ., pp. 83-89

Illoeje, NP (1978). A New Geography of Nigeria, Longman Nig. Ltd. pp. 34- 98

Irvine, TN; Baragar, WRA (1971), A guide to Chemical Classification of the common volcanic rocks. Canadian J. Earth Sci. vol. 8: 523-548.

McCurry, P (1976). The geology of the Precambrian to lower Palaeozoic rocks of northern Nigeria - a review. In: C. A. Kogbe (ed.), Geology of Nigeria, Elizabethan Publ. Co. Lagos. pp. 15-39.

Morsley, F. (1981). Methods in field geology. W.H. Freeman and Co. Ltd. Oxford $211 \mathrm{p}$

Obiora, SC (2012) Chemical characterisation and tectonic evolution of hornblende-biotite granitoids from the Precambrian Basement 
Complex around Ityowanye and Katsina-Ala, Southeastern Nigeria. J. Min. Geol. 48(1):13-29

Obiora SC (2006) Petrology and geotectonic setting of the Basement Complex rocks around Ogoja, Southeastern Nigeria. Ghana J. Sci. 46:13-46

Obiora, SC (2005) Field descriptions of hard rocks, with examples from the Nigerian Basement Complex. SNAAP Press (Nig.) Ltd., Enugu.

Obioha, YE; Ekwueme, BN (2011). Petrology and Chemical Composition of Gneisses of Northwest Obudu Plateau, Southeastern Nigeria. Global Journal of Pure and Applied Sci., 17: 215-226.

Oden, MI (2012). Strain partitioning and dimensional preferred orientation in a syn-tectonic Granitiod, Southeast Nigeria. Science World Journal. vol. 7(1): 9-14

Okonny, IP (1984). Igneous intrusion of Oban Massif area, using radar imagery. J. Min. Geol. 21(1+2):. 157-163.
Oluyide, PO (1988). Structural Trends in the Nigeria Basement Complex of Nigeria. A Publ. Geol. Society of Nigeria. pp 41-51.

Onyeagocha, AC; Ekwueme, BN (1982). The PrePan-African Structural features in North-Central Nigeria. Nigerian J. Min. Geol. 19: 74-77.

Oyawoye, MO (1972). The Basement Complex of Nigeria. In: African Geology edited by T. F. J. Dessauyagie and A. J. Whiteman. Univ. of Ibadan. Pp. 66-102.

Rahaman, MA (1976a) Review of the Basement Geology of Southwestern Nigeria. In: C.A. Kogbe (ed.) Geology of Nigeria. Elizabethan Publishing Company, Lagos. Pp. 41-57.

Rahaman, MA; Ukpong, EE; Azimatullah, M (1981). Geology of parts of the Oban massif, Nigeria. Jour. Min. Geol. 18: 60-65 